\title{
Improvement of Rumen Degradability to Low-quality Tropical Forage with the Addition of a Complete Supplement
}

\author{
Ramaiyulis ${ }^{1}$, Mardiati Zain ${ }^{2}$, RWS Ningrat ${ }^{2}$ and Lili Warly ${ }^{2}$ \\ \{ramaiyulis@gmail.com, mardiatiz@yahoo.com, oz.ningrat@gmail.com, liliwarly_uapdg@yahoo.co.id\} \\ Agricultural Polytechnic Payakumbuh, Tanjung Pati, Limapuluh Kota, Indonesia ${ }^{1}$ \\ Department Animal Science, Andalas University, Kampus Limau Manis, Padang, Indonesia ${ }^{2}$
}

\begin{abstract}
The low productivity of beef cattle is primarily due to the low rumen degradability of forage ration. This study aims to determine the level of addition complete supplement in improving rumen degradability to low quality tropical forages. The study was conducted in vitro using beef cattle rumen fluid treated with 4 levels of addtion complete supplement $(0,5,10$ and $15 \% \mathrm{DM})$ in tropical forage was paspalum conjugatum containing $\mathrm{CP} 5.41 \%$, NDF $56.47 \%$ and lignin $10.86 \%$. Complete supplements are prepared from red sugar, bran, coconut meal, soybean meal, tapioca, urea, salt and mineral, with addition of $10 \%$ gambier pulp as source of condensed tannin. The addition of a complete supplement at level $10 \%$ significant $(\mathrm{P}<0.01)$ increased rumen degradability of dry matter, organic matter, crude fiber and crude protein. The concentration of NH3 in rumen fluid increased significantly $(\mathrm{P}<0.01)$ at the supplement level of $10 \%$ while the TCA-soluble $\mathrm{N}$ increased significantly $(\mathrm{P}<0.01)$ at the $5 \%$ supplement level. But the $\mathrm{pH}$ and total VFA were not significant effect $(\mathrm{P}>0.05)$. Best level of complete supplement addition is $10 \%$ DM ration, while at level $15 \%$ gives negative tendency effect caused by negative effect of condensed tannin.
\end{abstract}

Keywords: complete supplement, beef cattle, tropical forage, rumen degradability, condensed tannin.

\section{Introduction}

In West Sumatera as well as in other parts of Indonesia, the development of beef cattle farm is was constrained in the provision of quality rations due to the limited source of quality feed and use competition with poultry farm resulting causes high prices so as not reached by the small farmers. This condition forces farmers to rely on beef cattle rations from native forages and is unable to provide concentrate feed. The low quality of tropical forage with low protein and rumen degradability [1] has led to lower rate of daily gain of beef cattle maintained on small farms [2].

Grass quality in tropical regions such as Indonesia is classified as low quality forage, has a protein content of less than $70 \mathrm{~g} / \mathrm{kg}$ of dry matter [3] and unbalanced nutritional content [4]. The grasses grow in coconut, rubber and palm oil plantations without maintenance, resulting in low quantity and quality [5]. Tropical forages contain low rumen degradable protein because most of the nitrogen is bound to the cell wall, thereby reducing the degradation of the 
forage crude protein which causes low ammonia $(\mathrm{N}-\mathrm{NH} 3)$ concentrations in rumen fluid thereby limiting microbial activity, resulting in low rumen degradability [6].

Supplementation of nitrogen compounds in the form of urea, biuret, casein belonging to rumen degradable protein is reported to improve rumen degradability [7]. Similarly, supplementation of fermentable energy compounds such as starch and starch with protein combinations can enhance rumen degradability and has interaction effects increase the growth rate of rumen microbes that play a role in fermentative processes in the rumen [8]. Supplementation of urea with sucrose in the form of molasses or brown sugar with mineral addition in urea molasses block and saka block has successfully improved the digestibility of low quality tropical forages and increase livestock productivity [9][10].

Table 1. Composition of rations and complete supplements

\begin{tabular}{|c|c|c|c|c|c|}
\hline Item & & $\mathbf{A}$ & B & $\mathbf{C}$ & D \\
\hline Forage, $\%$ & & 100 & 95 & 90 & 85 \\
\hline Complete Supplement, \% & & 0 & 5 & 10 & 15 \\
\hline Supplement Composition & $\% \mathrm{DM}$ & & & & \\
\hline Red sugar & 15 & & & & \\
\hline Bran & 27 & & & & \\
\hline Coconut meal & 12 & & & & \\
\hline Soybean meal & 15 & & & & \\
\hline Tapioca & 15 & & & & \\
\hline Urea & 5 & & & & \\
\hline Salt & 3 & & & & \\
\hline Minerals & 3 & & & & \\
\hline gambier pulp & 5 & & & & \\
\hline Chemical composition, $\%$ & & 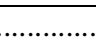 & $\% \mathrm{DM}$. & ............... & \\
\hline Organic matter & 86,13 & 90,33 & 90,18 & 89,63 & 89,88 \\
\hline Crude Protein & $29,36 \%$ & 5,41 & 6,10 & 8,46 & 9,46 \\
\hline $\mathrm{NDF}$ & 42,50 & 56,47 & 54,86 & 52,22 & 51,67 \\
\hline Lignin & 0,81 & 10,86 & 9,64 & 8,27 & 7,64 \\
\hline Catechin & 0,49 & 0 & 0,025 & 0,049 & 0,074 \\
\hline
\end{tabular}

In this study we will develop a complete feed supplement by combining block supplements that have evolved and understood the benefits with the addition of gambier pulp containing catechin as tannin condensation compounds to protect feed proteins. It is therefore desirable to have high rumen degradability by protecting quality protein to be available on post-rumen digestion.

\section{Materials and methods}

This study used a sample of low quality tropical forages from Paspalum conjugatum species taken on a smallholder farm in the Pariaman area of West Sumatra, Indonesia in the summer of March. This forage is a field grass that grows widely in the area of coconut plantations commonly used by farmers in this area as a source of forage in beef cattle farms. Complete supplements are prepared by formula Ramaiyulis et al [11] as shown in Table 1.

The treatment in this research is the level of complete supplement addition in ration that is $0,5 \%, 10 \%$ and $15 \%$ (DM basis) in low quality tropical forage. The study was conducted in 
vitro method following the Tilley and Terry procedure [12], using cattle rumen fluid extracted from slaughterhouses from traditionally raised cattle with full-forage without concentrate. The rumen fluid taken from 4 different cattle then brought to the laboratory using a heated flask. The rumen fluid was mixed with buffer solution [13] at a ratio of 1:4. Then the mixture was added to the fermentation bottle containing 2.5 grams of ration sample and no sample as a blank

After that into the bottle exhaled $\mathrm{CO}_{2}$ gas to create anaerobic conditions, then bottle closed and incubated at $39{ }^{\circ} \mathrm{C}$ using Shaker Waterbath. After 48 hours incubation the bottle soaked in ice water to stop the fermentation process. Then $\mathrm{pH}$ measurements using $\mathrm{pH}$ meters Hanna Hi9807-phep. The contents of the fermentor bottle were centrifuged at 3,000 rpm for 5 minutes to precipitate the remaining un-degraded feed and washed with aquadest 2 times with the same centrifuge and then filtered with Wathman 42 filter paper. Then the residue was dried in a $60{ }^{\circ} \mathrm{C}$ temperature oven for 24 hours, then determined dry matter, organic matter, crude protein and crude fiber following procedure of ICARDA [14].

The soluble rumen fluid nitrogen content in Tricloroacetic acids (TCA-soluble) was analyzed following the Shultz and Shultz procedure [15] using $10 \mathrm{ml}$ of rumen fluid plus 10 $\mathrm{ml}$ of TCA $20 \%$ and $10 \mathrm{ml}$ of sulfoacetic acid (SSA) was allowed to stand for 1 hour, then centrifuged 3,000 rpm for 20 minutes then the resulting sedimentation results analyzed protein content.

The total VFA in rumen fluid were determined on $5 \mathrm{ml}$ supernatan with steam destilation, while NH3 in rumen fluid was determined by analyzing $1 \mathrm{ml}$ of supernatant mixed with saturated $\mathrm{NaCO} 3$ in Conway cup, both following procedure of the General Laboratory Procedure [16].

Data were analyzed statistically using analysis of variance (ANOVA) with block randomized design and to test the real difference between treatments, Duncan's mulltiple range test (DMRT) [17]. The regression analysis were used to examine the relationship between factors of treatments. Data processing is done by computer using application of Statistica version 10 and Microsoft Excel 2010.

\section{Result and Discussion}

\section{Rumen degradability}

The results of the study in Table 2 showed that the addition of complete supplement was highly significant $(\mathrm{P}<0.01)$ increasing the rumen degradability of dry matter, organic matter and crude protein of low-quality tropical forage rations. Increased rumen degradation occurs after the addition of supplements at the level of $10 \%$ of dry matter rations. The 5\% supplement level did not significantly with the control, while the $15 \%$ level did not significantly with the $10 \%$ level. Means that the complete supplement level of $10 \%$ has optimally improved the rumen degradability of dry matter, organic matter and crude protein from low quality tropical forages.

The addition of complete supplements in ration of low-quality tropical forage caused an increase in crude protein content of the ration from 5.41 to $9.46 \%$ (table 1), this correlates closely with rumen degradability of dry matter $\left(P=0.04 ; \mathrm{R}^{2}=0.91\right)$, organic matter $(\mathrm{P}=$ $\left.0.05 ; \mathrm{R}^{2}=0.90\right)$ and crude protein $\left(\mathrm{P}=0.05 ; \mathrm{R}^{2}=0.90\right)$. In this study we found that the crude protein level that gives optimal rumen degradability of dry matter, organic matter and crude protein is $8.46 \%$ ie in the addition of supplements at level $10 \%$ of dry matter rations. For 
comparison Lazzarini et al. [18]reported that the optimal organic matter rumen degradability of low-quality forage was found at the crude protein level of $7.93 \%$ in ration.

Increased crude protein content in ration of low quality tropical forage due to the provision of adequate nitrogen for the formation of microbial enzymes that play a role in feed degradation [19]. Therefore increasing the rough protein of ration through the administration of easily degradable proteins with the addition of urea may stimulate rumen microbial activity and improve the degradation of organic matter, forage intake and livestock productivity in low quality tropical forage rations [7], [19].

If the supplement level is increased to the highest level (15\%) in this study is not significant $(\mathrm{P}>0.05)$ gives an increase effect compared to the level of $10 \%$. This is due to the condensed tannin content in the gambier pulp which increases its concentration in the ration (Table 1). At the supplement level of $15 \%$ there is $0.067 \%$ catechin concentration in the ration which causes inhibition of dry matter digestibility, organic matter and crude protein. Catechin is a condensed tannin capable of forming complex bonds with proteins that are resistant to degradation at neutral $\mathrm{pH}$ in the rumen and one of the strategies in optimizing the use of nitrogen in ruminants [20]. Based on the results of meta analysis it was reported that in condensed tannins caused decreased digestibility of organic matter and crude protein in both in vitro and in vivo on centain level, but at low levels showed varying effects [21].

The effect of addition coplete supplement on the rumen degradability of crude fiber of low quality tropical forage showed highly significant effect $(\mathrm{P}<0.01)$. The lowest degradability occurs in the control without addition complete supplement that is only $35.76 \%$. Addition of complete supplement at level $10 \%$ increased rumen degradability of crude fiber to $53.80 \%$, but decreased again at a higher level on $15 \%$ to $46.78 \%$. The addition of complete supplement to level $10 \%$ gives a positive influence on crude fiber degradability, this is due to the availability of nutrients needed by microbes that stimulate the activity of rumen microbes in degrading crude fiber of feed.

The decrease in the rumen degradability of crude fiber on addition complete supplement at level 15\% occurs due to the content of the condensed tannin (catechin) compound in the gambier pulp. Tannins interact and inhibit the protein and fiber degradation in rumen [9], [22], [23] Wischer et al. [23] reported a significant decrease in fiber degradation by the tannin treatment of pelargonidine, catechin, cyanidin and sinapinic acid compounds, suggesting that fiber degradation was inhibited by condensed tannin treatment at level.

\section{Rumen fluid Concentration}

$\mathrm{pH}$ of rumen fluid influences rumen microbial activity especially cellulolytic bacteria which is expected to work optimally degrade high fiber rations of low quality forage. The addition of complete supplements did not show a significant effect on rumen $\mathrm{pH}(\mathrm{P}=0.11)$. The $\mathrm{pH}$ range obtained in this study was 6,90-6,97 which was at optimum $\mathrm{pH}$ for cellulolytic bacteria activity that is 6,9-7,0 [24]. Cellulolytic bacteria activity will be inhibited if the rumen fluid $\mathrm{pH}$ is below 6.0 [25].

The effect of addition complete supplement on low quality tropical forage on total VFA concentration in rumen fluid showed no significant difference $(\mathrm{P}=0.12)$. VFA is derived from the fermentation of structural carbohydrates ie NDF and ADF fiber components in forage and non structural carbohydrates such as starch and sucrose contained in complete supplement. The process of carbohydrate degradation in the rumen occurs through two stages: breaking complex carbohydrates into simple sugars and simple sugar breakdowns into acetic acid, propionic acid, butyric acid, $\mathrm{CO} 2$ and $\mathrm{CH} 4$ [26]. In this study the total VFA concentrations ranged from $85.50-99.25 \mathrm{mM}$, the resulting VFA concentration was sufficient for livestock 
survival because the VFA concentrations required for a livestock to grow normally ranged from 70-130 $\mathrm{mM}$ [27].

The NH3 concentration in rumen fluid in this study was lowest 2.40 in the controls and the highest was found in the addition of $10 \%$ supplement 4.63 and significantly $(\mathrm{P}<0.01)$ influenced by the addition of complete supplements. NH3 is the final product of crude protein degradation by rumen microbes through some of the previous products of polypepetide, amino acids and the last ammonia (NH3). Several factors affecting NH3 concentration in rumen fluid are feed protein level, protein source and its solubility and feed protein degradation rate [28].

The Complete supplement containing urea as crude protein and protected feed protein by condensed tannin from gambier pulp. At the complete supplement level of $10 \%$ there was an increase in crude protein degradation from control $39.29 \%$ to $53.68 \%$. This is also reflected in the increased NH3 concentration in rumen fluid from control to the $10 \%$ supplement level. However, at a higher supplement level of $15 \%$ there has been a protection of protein degradation because condensed tannins form a complex bond with proteins that are resistant to rumen degradation causing $\mathrm{NH} 3$ concentrations that are not significantly different at that level.

The addition of a complete supplement significantly increased TCA-soluble $\mathrm{N}$ from the $5 \%$ level $(\mathrm{P}<0.01)$. The lowest values of these parameters were found in controls and highest in the addition of a complete supplement level of $10 \%$. In control, the lowest score was 76.67 $\mathrm{mg} / \mathrm{dl}$ of rumen fluid, significantly increased to $113.52 \mathrm{mg} / \mathrm{dl}$ after the addition of a complete supplement of $5 \%$ and $125.03 \mathrm{mg} / \mathrm{dl}$ at a complete supplement level of $10 \%$. Apparently, if the supplement level is increased by more than $5 \%$ there is an increasing trend but not statistically significant.

TCA-soluble $\mathrm{N}$ contains proteins, peptides and amino acids derived from non-degraded feed proteins and proteins from rumen microbes, these are the values of proteins that will enter the post-rumen digestion. The increasd of TCA-solubel $\mathrm{N}$ is a plus value of a complete supplement, in which the benefits of supplements are able to provide nutrients for optimal rumen microbial activity in degrading feed nutrients and capable of protecting high-quality feed protein so that it can be readily available in post-rumen. So the level addition of complete supplement should be limited to $10 \%$, because the condensed tannin compound in the complete supplement has a negative effect on the higher supplement level.

Table 2. In vitro Rumen degradability and rumen fluid concentration to low quality tropical forage with addition complete supplement

\begin{tabular}{|c|c|c|c|c|c|c|}
\hline \multirow{2}{*}{ Parameter } & \multicolumn{4}{|c|}{ Supplement level (\% DM ration) } & \multirow{2}{*}{ SEM $^{1}$} & \multirow{2}{*}{$P$-value } \\
\hline & 0 & 5 & 10 & 15 & & \\
\hline \multicolumn{7}{|l|}{ Rumen Degradability, \% } \\
\hline Dry matter & $49.01^{\mathrm{b}}$ & $49.70^{b}$ & $51.97^{\mathrm{a}}$ & $51.66^{\mathrm{a}}$ & 0.01 & $<0.01$ \\
\hline Organic matter & $43.80^{\mathrm{b}}$ & $44.33^{\mathrm{b}}$ & $46.59^{\mathrm{a}}$ & $46.21^{\mathrm{a}}$ & 0.01 & $<0.01$ \\
\hline Crude protein & $39.29^{\mathrm{b}}$ & $37.12^{\mathrm{b}}$ & $53.68^{\mathrm{a}}$ & $53.58^{\mathrm{a}}$ & 0.02 & $<0.01$ \\
\hline Crude fiber & $35.76^{\mathrm{d}}$ & $42.50^{c}$ & $53.80^{\mathrm{a}}$ & $46.78^{\mathrm{b}}$ & 0.01 & $<0.01$ \\
\hline \multicolumn{7}{|l|}{ Rumen fluid concentration } \\
\hline $\mathrm{pH}$ & 6.90 & 6.90 & 6.94 & 6.97 & 0.03 & 0.11 \\
\hline VFA total $(\mathrm{mM})$ & 99.25 & 85.50 & 91.25 & 95.00 & 4.54 & 0.12 \\
\hline $\mathrm{NH} 3(\mathrm{mg} / \mathrm{dl})$ & $2.40^{\mathrm{c}}$ & $3.85^{\mathrm{b}}$ & $4.63^{\mathrm{a}}$ & $4.25^{\mathrm{a}}$ & 0.16 & $<0.01$ \\
\hline TCA-soluble N, mg/dl & $76,67^{\mathrm{b}}$ & $113,52^{\mathrm{a}}$ & $125,03^{\mathrm{a}}$ & $122,12^{\mathrm{a}}$ & 8,31 & $<0.01$ \\
\hline
\end{tabular}

Different superscripts on the same line showed significantly different effects 


\section{Conclusion}

The conclusions of the results of this study are the addition of complete supplements can improve the rumen degradability of dry matter, organic matter, crude fiber and crude protein of low quality tropical forage. The addition of the optimal complete supplement is $10 \%$ of ration dry matter for optimal rumen degradability and the rumen fluid concentration that supports the growth and activity of rumen microbes. The addition of a complete supplement increases TCA-soluble $\mathrm{N}$ that is the protein that will be available in the post-rumen digestion.

\section{Acknowledgements}

We would said thank you to my promoter and copromotor on the Doctoral Program of Animal Science on Animal Husbandry Faculty at Andalas University. His services have provided much input in the writing of this paper.

\section{References}

[1] N. Nasrullah, M. Niimi, R. Akashi, and O. Kawamura, "Nuritive evalution of forage plants grown in South Sulawesi, Indonesia," Asian-Australasian J. Anim. Sci., vol. 16, no. 5, pp. 693 701, 2003.

[2] M. F. Wiyatna, "Produktivitas Sapi Peranakan Ongole pada Peternakan Rakyat di Kabupaten Sumedang (Productivity of Peranakan Ongole Cattle on traditional farm system in Sumedang Region)," J. Ilmu Ternak, vol. 12, no. 2, 2012.

[3] M. A. Souza, E. Detmann, M. F. Paulino, C. B. Sampaio, Í. Lazzarini, and S. C. Valadares Filho, "Intake, digestibility and rumen dynamics of neutral detergent fibre in cattle fed lowquality tropical forage and supplemented with nitrogen and/or starch," Trop. Anim. Health Prod., vol. 42, no. 6, pp. 1299-1310, 2010.

[4] B. W. Norton, "Differences between species in forage quality," in Nutritional Limits to Animal Production from Pastures: proceedings of an international symposium held at St. Lucia, Queensland, Australia, August 24-28, 1981/edited by JB Hacker, 1982.

[5] V. Heuzé, G. Tran, D. Sauvant, and F. Lebas, "Buffalo grass (Paspalum conjugatum)," Feedipedia, a programme by INRA, CIRAD, AFZ and FAO, 2016. [Online]. Available: https://www.feedipedia.org/node/407. [Accessed: 01-Apr-2017].

[6] M. F. Paulino, E. Detmann, E. E. L. Valente, and L. V. de Barros, "Nutrição de bovinos em pastejo," Simpósio sobre manejo estratégico da pastagem, vol. 4, no. 2008, pp. 131-169, 2008.

[7] C. B. Sampaio et al., "Intake and digestibility in cattle fed low-quality tropical forage and supplemented with nitrogenous compounds," Trop. Anim. Health Prod., vol. 42, no. 7, pp. 1471-1479, 2010.

[8] J. S. Heldt et al., "Effects of different supplemental sugars and starch fed in combination with degradable intake protein on low-quality forage use by beef steers," J. Anim. Sci., vol. 77, no. 10, pp. 2793-2802, 1999.

[9] H. P. S. Makkar, M. Sánchez, and A. W. Speedy, "Feed supplementation blocks.(ser. FAO animal production and health paper, no. ser. 164)," Rome, Italy Food Agric. Organ. United Nations, 2007.

[10] S. A. Abutani, S. Rahim, and N. Noverma, "Respon Pemberian 'Blok Suplemen' Berbasis Bahan Lokal Terhadap Pertambahan Bobot Sapi Bali,” J. Sain Peternak. Indones., vol. 5, no. 1, pp. 65-69, 2010. 
[11] Ramaiyulis, R. Ningrat, M. Zain, and L. Warly, "Proteksi protein pakan suplemen dengan penambahan ampas gambir terhadap laju degradasinya secara In Vitro," in Seminar Nasional Sapi dan Kerbau III, 2017.

[12] J. M. A. Tilley and R. A. Terry, "A two-stage technique for the in vitro digestion of forage crops," Grass forage Sci., vol. 18, no. 2, pp. 104-111, 1963.

[13] E. I. McDougall, "Studies on ruminant saliva. 1. The composition and output of sheep's saliva," Biochem. J., vol. 43, no. 1, p. 99, 1948.

[14] M. Zaklouta, M. Hilali, A. Nefzaoui, and M. Haylani, "Animal nutrition and product quality laboratory manual," ICARDA, Aleppo, Syria. viii, 2011.

[15] T. A. Shultz and E. Shultz, "Estimation of rumen microbial nitrogen by three analytical methods," J. Dairy Sci., vol. 53, no. 6, pp. 781-784, 1970.

[16] University of Wiscounsin-Medison, GLP (General Laboratory Procedures). Department of Dairy Science, University of Wiscounsin Medison, 1986.

[17] K. A. Gomez and A. A. Gomez, "Statistical procedures for agricultural research with emphasis on rice.," Stat. Proced. Agric. Res. with Emphas. rice., 1981.

[18] I. Lazzarini et al., "Intake and digestibility in cattle fed low-quality tropical forage and supplemented with nitrogenous compounds," Rev. Bras. Zootec., vol. 38, no. 10, pp. 20212030, 2009.

[19] E. Detmann et al., "Parameterization of ruminal fibre degradation in low-quality tropical forage using Michaelis-Menten kinetics," Livest. Sci., vol. 126, no. 1-3, pp. 136-146, 2009.

[20] S. Calsamiglia, A. Ferret, C. K. Reynolds, N. B. Kristensen, and A. M. Van Vuuren, "Strategies for optimizing nitrogen use by ruminants," Animal, vol. 4, no. 7, pp. 1184-1196, 2010.

[21] A. Jayanegara and E. Palupi, "Condensed tannin effects on nitrogen digestion in ruminants: A meta-analysis from in vitro and in vivo studies," Media Peternak., vol. 33, no. 3, p. 176, 2010.

[22] H. P. S. Makkar, Quantification of tannins in tree and shrub foliage: a laboratory manual. Springer Science \& Business Media, 2003.

[23] G. Wischer, J. Boguhn, H. Steingaß, M. Schollenberger, and M. Rodehutscord, "Effects of different tannin-rich extracts and rapeseed tannin monomers on methane formation and microbial protein synthesis in vitro," Animal, vol. 7, no. 11, pp. 1796-1805, 2013.

[24] J. B. Russell and D. B. Wilson, "Why are ruminal cellulolytic bacteria unable to digest cellulose at low pH?," J. Dairy Sci., vol. 79, no. 8, pp. 1503-1509, 1996.

[25] F. L. Mould, E. R. Ørskov, and S. O. Mann, "Associative effects of mixed feeds. I. Effects of type and level of supplementation and the influence of the rumen fluid $\mathrm{pH}$ on cellulolysis in vivo and dry matter digestion of various roughages," Anim. Feed Sci. Technol., vol. 10, no. 1, pp. 15-30, 1983.

[26] P. McDonald, R. A. Edward, J. F. D. Greenhalgh, and C. A. Morgan, Animal Nutrition, 6th ed. Scientific and Tech John Willey \& Sons, 2002.

[27] W. Suryapratama, "Efek suplementasi asam lemak volatile bercabang dan kapsul lisin serta treonin terhadap nutrisi protein sapi holstein," Disertasi. Progr. Pascasarjana, Inst. Pertan. Bogor, Bogor, 1999.

[28] B. P. Widyobroto, S. P. S. Budhi, and A. Agus, "Effect of undegraded protein and energy level on rumen fermentation parameters and microbial protein synthesis in cattle," J. Indones. Trop. Anim. Agric., vol. 32, no. 3, pp. 194-200, 2007. 